\title{
Beslenme desteği tipi hematopoetik kök hücre nakil sonuçlarını etkiliyor mu? Bir pediatrik merkez deneyimi
}

Does the type of nutritional support affect the outcome of hematopoietic stem cell transplantation? A pediatric center experience

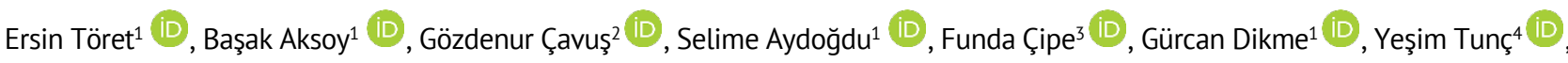 \\ Tunç Fışgın ${ }^{1}$, Ceyhun Bozkurt ${ }^{1}$ i
}

1 Çocuk Hematoloji-Onkoloji BD, Altınbaş Üniversitesi Bahçelievler Medicalpark Hastanesi, İstanbul/Türkiye
2 Beslenme ve Diyet Uzmanı, Altınbaş Üniversitesi Bahçelievler Medicalpark Hastanesi, İstanbul/Türkiye
3 Çocuk Allerji-İmmünoloji Uzmanı, Altınbaş Üniversitesi Bahçelievler Medicalpark Hastanesi, İstanbul/Türkiye
4 Biyoistatistik ve Tıbbi Bilişim ABD, Altınbaş Üniversitesi Bahçelievler Medicalpark Hastanesi, İstanbul/Türkiye

\section{ÖzeT}

AMAÇ: Hematopoetik kök hücre nakli (HKHN) çocukluk çağının benign ve malign pek çok hastalığı için küratif tedavi seçeneğidir. Hastalara kök hücre infüzyonundan önce uygulanan tedaviler ve hastaların anksiyetesi beslenmelerinin bozulmasına neden olur. Beslenmenin bozulması sonucu gelişen malnütrisyon hastaların yaşam kalitesini ve tedavi başarısına negatif yönde etkiler. Nazogastrik sonda (NGS) ile beslenme, gastrointestinal yolu fonksiyonel tutması ve daha fizyolojik olması nedeniyle ön plana çıkmıştır. Bu araştırmada nakil sürecinde farklı beslenme yöntemleri uygulanan üç grup tedavi sonuçları ve komplikasyonlar açısından karşılaştırılması amaçlanmıştır.

GEREÇ VE YÖNTEM: Iki bin on beş ile 2019 yılları arasında allojenik HKHN uygulanan 97 olgu beslenme yöntemlerine göre nazogastrik sonda ile enteral, total parenteral nütrisyon ve karışık tip enteral ve parenteral birlikte) olmak üzere üç gruba ayrıldı. Tüm olguların demografik özellikleri (yaş, cins, tanı), nötrofil ve trombosit engraftman zamanları ve komplikasyon varlığı kayıt altına alındı. Veriler istatiksel yöntemler kullanılarak incelendi.

BULGULAR: Ortanca nakil yaşları 8.5 yıl (6 ay-17 yıl) olan 97 olguya (55 erkek, 42 kIz) allojenik HKHN sırasında 33 'üne enteral, 32'sine parenteral ve yine 32'sine karışık tip beslenme uygulandı. Grupların yatış süreleri, ortanca trombosit engraftman zamanları ve mukozit süreleri açısından enteral beslenen grupta diğer iki gruba göre istatiksel anlamlı fark saptandı. Ayrıca Nakil sonrası komplikasyonlar için değerlendirme yapıldığında enteral beslenen grupta diğer iki gruba göre akut GvHH (derece I-IV) ve CMV enfeksiyonu gelişimi açısından istatiksel anlamlı fark saptandı.

SONUÇ: Enteral beslenme naklin başarısını olumlu etkisi ve maliyeti etkin bir yöntem olmanın yanı sıra nakil sonrası komplikasyonların azalmasını sağlar.

Anahtar Kelimeler: çocukluk çağı, hematopoetik kök hücre nakli, beslenme

\section{ABSTRACT}

OBJECTIVE: Hematopoietic stem cell transplantation (HSCT) is a curative treatment option for many benign and malignant childhood diseases. Treatments that are given to patients before stem cell infusion and anxiety cause malnutrition. Malnutrition affects patients' quality of life and treatment success negatively. Nasogastric catheter (NGS) feeding has become more prominent in the last years due to the fact that the gastrointestinal tract is functional and more physiological. The aim of this study was to compare three groups of treatment methods and complications with different feeding methods during transplantation.

MATERIALS AND METHODS: Ninety seven patients who underwent allogeneic HSCT between 2015 and 2019 were divided into three groups as enteral feeding with nasogastric tube, total parenteral nutrition and mixed type (enteral and parenteral) according to feeding methods. Demographic characteristics (age, sex, and diagnosis), neutrophil and platelet engraftment times and the presence of complications were recorded. Data were analyzed using statistical methods.

RESULTS: Ninety seven patients (55 males, 42 females) with median transplantation age of 8.5 years (6 months-17 years) underwent enteral feeding in 33, parenteral feeding in 32, and mixed feeding in 32 patients. There was a statistically significant difference between the enteral group and other two groups in terms of hospitalization time, median platelet engraftment time and mucositis time. When post-transplant complications were evaluated, a statistically significant difference was found between the enteral group and other two groups in terms of acute GVHD (grade I-IV) and CMV infection.

Yazışma Adresi/Address for Correspondence: Ersin Töret, MD, Çocuk Hematoloji-Onkoloji BD, Altınbaş Üniversitesi Bahçelievler Medicalpark Hastanesi E-Posta/E-Mail: etoret@ogu.edu.tr || Tel: +90 5057994234

Received/Geliş Tarihi: 07 Kas 2019 || Accepted/Kabul Tarihi: 27 Kas 2019

Bu Eser Creative Commons Atıf-Gayriticari 4.0 Uluslararası Lisansı İle Lisanslanmıştır. This work is licensed under a Creative Commons

Attribution-NonCommercial 4.0 International License (CC BY-NC 4.0). 
CONCLUSION: Enteral nutrition has a positive effect on the success of transplantation and provides a cost effective method as well as a reduction of post-transplant complications.

Keywords: childhood, hematopoietic stem cell transplantation, nutrition

\section{GíRiş}

Hematopoetik kök hücre nakli (HKHN) çocukluk çağının benign ve malign pek çok hastalı̆̆ı için küratif tedavi seçeneğidir. Hastalara kök hücre infüzyonundan önce uygulanan kemoterapi, radyoterapi veya diğer tedavilerin yanı sıra tedavi anksiyetesi beslenmelerinin bozulmasına neden olur $(1,2)$. Hücre infüzyonu sonrası gelişen enfeksiyonlar (CMV gibi) ve akut graft versus host hastalığı (GvHH) gibi komplikasyonların da katkısıyla malnütrisyon kaçınılmaz olur. Malnütrisyon hastaların yaşam kalitesini ve tedavi başarısını negatif yönde etkilerken, başarılı beslenme desteği erken engraftman, daha kısa süreli hastane yatışı ve daha düşük maliyet gibi pek çok pozitif etki oluşturur $(3,4)$. Geleneksel olarak parenteral beslenme güvenli ve etkin bir yöntem olması dolayısıyla tercih edilirken son yıllarda nazogastrik sonda (NGS) ile beslenme, gastrointestinal yolu fonksiyonel tutması ve daha fizyolojik olması nedeniyle ön plana çıkarılmıştır (5). Hem Avrupa hem de Amerika Beslenme Toplulukları barsak fonksiyonları normal olan tüm hastalarda ilk tercih beslenme yöntemi olarak enteral yolu önerir (6). Bu araştırmada nakil sürecinde farklı beslenme yöntemleri uygulanan üç grubun tedavi sonuçları ve komplikasyonlar açısından karşılaştırılması amaçlanmıştır..

\section{GEREÇ VE YÖNTEM}

İki bin on beş ile 2019 yılları arasında allojenik HKHN uygulanan 97 olgu beslenme yöntemlerine göre enteral, parenteral ve karışık tip olmak üzere üç gruba ayrıldı. Hastaların beslenmeleri günlük kalori ve protein intiyaçlarını karşılayacak şekilde diyetisyen önerisine göre düzenlenmektedir. TPN otomatik cihazlarda steril şekilde hazırlanmaktadır. Olguların tamamı birinci ve üçüncü ayda tam kimerik ve nakil sonrası ilk 100 gün hayatta kalanlardan seçildi. Enteral gruptaki olgular nakil hazırlama rejimi devam ederken en geç -1. günde (hücre infüzyonundan bir önceki gün) nazogastrik sonda (NGS) takılarak en az yedi gün süreyle bu yöntemle beslenen olgulardan oluştu. Parenteral beslenme grubunda oral alımı kısıtlayan ciddi mukozit, kusma gibi nedenlerle beslenemeyen ancak NGS takılmasını kabul etmeyen veya takılması uygun olmayan (ağır mukoziti veya damak-dudak malformasyonu olan olgular gibi) olgulardan en az yedi gün total parenteral nütrisyon (TPN) uygulanan olgulardan oluştu. Karışık tip beslenme grubu en az yedişer gün hem NGS yoluyla hem de TPN uygulanan olgulardan oluştu. Tüm olguların demografik özellikleri (yaş, cins, tanı), nötrofil ve trombosit engraftman zamanları ve komplikasyon varlığı kayıt altına alındı. Nötrofil engraftmanı ardışık 3 gün boyunca desteksiz mutlak nötrofil sayısının (MNS)> 0,5×10-9/L üzerinde olduğu ilk gün, trombosit engraftmanı ardışık 5 gün boyunca trombositlerin 20x10-9/L üzerinde olduğu ilk gün olarak kabul edildi. Olgulardan nakil öncesi hazırlık aşamasında ve nakil sonrası iki hafta aralarla BK virüs enfeksiyonu açısından PCR ile yapılan taramalar da kayıt altına alındı. Çalışma için kurum izni Altınbaş Üniversitesi Tıp Fakültesi Dekanlığından alındı. Veriler SPSS 15.0 istatistik programında çalışıldı.

\section{BULGULAR}

Ortanca nakil yaşları 8,5 yıl (6 ay-17 yıl) olan 97 olguya (55 erkek, 42 kız) Ocak 2015 ile Ocak 2019 tarihleri arasında allojenik HKHN uygulandı. Olgulardan 33'ü enteral, 32'si parenteral ve yine 32'si karışık tip beslenme grubunda yer aldı. Ortanca yatış süreleri enteral beslenen grupta 33.9 gün (21-60 gün), parenteral beslenen grupta 43 gün (29-69 gün) ve karışık tip beslenen grupta 41.9 gün (29-76 gün) olarak hesaplandı. Grupların yatış süreleri arasında enteral beslenen grupta diğer iki gruba göre istatiksel anlamlı fark saptandı $(p<0.05)$. Ortanca nötrofil ve trombosit engraftman zamanları enteral beslenen grupta 14,5 gün (10-20 gün) ve 19 gün (10-45 gün), parenteral beslenen grupta 15.1 gün (10-33 gün) ve 26.2 gün (12-51 gün), karışık tip beslenen grupta 14.3 gün (10-20 gün) ve 24.9 gün (10-40 gün) saptandı. Gruplar arasında nötrofil engraftman zamanı açısından istatiksel fark saptanmazken trombosit engraftman zamanları arasında enteral beslenen grupta diğer iki gruba göre istatiksel anlamlı fark saptandı $(p<0.05)$. Ayrıca gruplar arasında mukozit süreleri açısından istatiksel anlamlı fark saptandı $(p<0.05)$. Beslenme grupları arasında olguların hastalıklarında istatiksel fark saptanmadı ( $p>0.05$ ). Tablo 1'de olguların demografik ve nakil özellikleri özetlendi. Nakil sonrası komplikasyonlar için değerlendirme yapıldığında akut GvHH (derece I-IV) ve CMV enfeksiyonu 
açısından gruplar arasında istatiksel anlamlı fark saptandı $(p<0.05)$. Veno-oklüziv obstrüksiyon sendromu, hemorajik sistit ve kateter enfeksiyonu açısından fark saptanmadı
( $p>0.05)$. Olguların nakil sonrası komplikasyonlarının değerlendirmesi Tablo 2'de gösterildi.

Tablo 1. Hastaların demografik ve nakil özellikleri

\begin{tabular}{|c|c|c|c|c|}
\hline & Enteral & $\begin{array}{l}\text { Beslenme Tipi } \\
\text { Parenteral }\end{array}$ & Enteral + Parenteral & P değeri \\
\hline $\mathbf{N}$ & 33 & 32 & 32 & \\
\hline Cins (Erkek/Kız) & $21 / 12$ & $17 / 15$ & $17 / 15$ & 0.616 \\
\hline Nakil Yaşı (yıl) & $8.4(0.5-16)$ & $8.9(0.5-17)$ & $8.1(1.5-16)$ & 0.972 \\
\hline Yatış Süresi (gün) & $33.9 *(21-60)$ & $43.0(29-69)$ & $41.9(29-76)$ & 0.001 \\
\hline Nötrofil Engraftman (gün) & $14.5(10-20)$ & $15.1(10-33)$ & $14.3(10-20)$ & 0.629 \\
\hline Trombosit Engraftman (gün) & $19.0 *(10-45)$ & $26.2(12-51)$ & $24.9(10-40)$ & 0.006 \\
\hline Mukozit Süresi (gün) & $7.8 *(0-16)$ & $7.2^{*}(0-15)$ & $11.1(0-20)$ & 0.007 \\
\hline \multicolumn{5}{|l|}{ Beslenme süresi (gün) } \\
\hline Enteral & $10.1(0-23)$ & - & $13.2(7-20)$ & \\
\hline Parenteral & - & $12.1(5-20)$ & $13.3(7-20)$ & \\
\hline \multicolumn{5}{|l|}{ Altta yatan hastalık } \\
\hline AML/ALL/MDS & 11 & 15 & 16 & \multirow{5}{*}{0.326} \\
\hline AA & 3 & 6 & 3 & \\
\hline FAA & - & 2 & 2 & \\
\hline İmmün yetmezlik & 6 & 4 & 1 & \\
\hline Talasemi & 13 & 5 & 10 & \\
\hline
\end{tabular}

p < 0.05. *: anlamlı farkın olduğu grup, AML; akut myelositer lösemi, ALL; alut lenfoblastik lösemi, MDS; myelodisplastik sendrom, AA; aplastik anemi, FAA; fankoni aplastik anemi.

Tablo 2. Nakil sonrası komplikasyonların beslenme tipine göre dağılımı

\begin{tabular}{|c|c|c|c|c|}
\hline & \multicolumn{3}{|c|}{ Beslenme Tipi } & \multirow[b]{2}{*}{$P$ değeri } \\
\hline & Enteral & Parenteral & Enteral + Parenteral & \\
\hline $\mathbf{N}$ & 33 & 32 & 32 & \\
\hline SOS & 3 & 10 & 5 & 0.064 \\
\hline Akut GVHD & $1 *$ & $3 *$ & 14 & 0.000 \\
\hline CMV & 9* & 9* & 18 & 0.024 \\
\hline Hemorajik sistit & 3 & 4 & 4 & 0.883 \\
\hline Kateter Enfeksiyonu & 7 & 10 & 8 & 0.650 \\
\hline
\end{tabular}

p <0.05, *: istatiksel anlamlı farkın olduğu grup(lar), SOS: sinüzoidal obstrüksiyon sendromu, GvHH; graft versus host hastalığı, CMV; sitomegalovirüs,

\section{TARTIŞMA}

Allojenik HKHN uygulanan hastalarda etkin kalori alımını sağlamak nakil başarısını belirleyen faktörler arasında yer alır. Enteral beslenme fizyolojiye uygun ve maliyeti düşük bir yöntem olmasına rağmen bazı ağır olgularda parenteral beslenme gerekebilir. Nakil hazırlık aşamasında gastrointestinal komplikasyonlar gelişmeden takılan NGS tolerasyonu hastaların için daha mümkün olmaktadır. Enteral beslenme ile izlem devam ederken gelişen ağır komplikasyonlarda parenteral beslenmeye geçiş nedeni olabilir $(7,8)$.

Enteral beslenmenin tüm sağ kalım, hastalık tekrarı dışı mortaliteyi azaltmanın yanı sıra hastane kalış süresini kısalttığı bilinmektedir $(7,9)$. Bu çalışmada enteral beslenen grupta hastane yatış süresi istatiksel anlamlı azalmış saptandı. Seguy ve ark. (10) erişkin yaş grubunda yaptıkları çalışmalarında enteral beslenen grupta nötrofil ve platelet engraftmanı anlamlı daha erken geliştiği, Gonzalez ve ark. (9) ve Azarnoush ve ark. (7) çalışmalarında ise platelet engraftmanının daha erken geliştiği gösterilmiştir. Bu çalışmada da platelet engraftmanının enteral beslenen grupta diğer iki gruba göre istatiksel anlamlı olarak daha erken geliştiği gösterilmiştir. Seguy ve ark. (10) enteral ve enteral dışı beslenen iki grubu kıyasladıkları çalışmalarında mukozit süresi ve derecesi açısından fark saptamamışlardır. Gonzalez ve ark. (9) ile Guieze ve ark. (6) çalışmalarında da enteral ve parenteral beslenen gruplar arasında ağır mukozit gelişimi bakımından fark saptanmamıştır. Bu çalışmada enteral beslenen grupta mukozit süresi anlamlı kısalmış olarak saptandı. Mukozit süresinin kısa olması barsak fonksiyonlarının sürdürülmesinin olumlu bir sonucu olarak yorumlandı.

Hematopoetik kök hücre nakli sonrası mortalitesi en yüksek komplikasyonu GvHH'dır (11). Enteral beslenme intestinal 
atrofiyi engellemenin yanı sıra bakteriyel translokasyonu da önleyerek yine gastrointestinal GvHH oranını azaltır. Önceki çalışmalarda da gösterildiği gibi bu çalışmada da GvHH riskinin enteral beslenme ile azaldığı saptandı $(7,9,10,12)$. Sitomegalovirüs (CMV), Ebstein-Bar virüs (EBV) ve Human Herpes Virüs 6 (HHV6) reaktivasyonu açısından değerlendirme yapan Guieze ve ark. (6) çalışmasında fark saptanmazken bu çalışmada CMV reaktivasyonu enteral beslenen grupta anlamlı azalmış olarak saptandı. Parenteral beslenme kolestaz gelişmesine neden olarak karaciğerin veno-okluziv hastalığını tetikleyebileceği bildirilse de (6), Azarnoush ve ark. (6) ve bu çalışmada hastalık gelişimi açısından fark saptanmamıştır. Ayrıca parenteral beslenme kateter enfeksiyon riskini artırmaktadır $(10,14)$. Guieze ve ark. (6) çalışmasında parenteral beslenen grupta enfeksiyon nedeniyle daha fazla kateterin çıkarıldığı gösterilse de bu çalışmada da olduğu gibi istatiksel fark saptanmamıştır. Allojenik HKHN sonrası BK virüs ilişkili hemorajik sistit sık komplikasyonlardandır (15). Bu çalışmada toplam 11 (\%11) olguda gelişen bu komplikasyon için gruplar arası fark saptanmadı.

Son olarak bu çalışmada maliyet karşılaştırmasına izin verecek veriler bulunmamasına rağmen yatış süresi kısa, komplikasyonların daha az olması dolayısıyla önceki çalışmalar da gösterildiği gibi enteral beslenmenin maliyet etkin bir yöntem olduğunu düşünüyoruz $(4,6,9,10)$.

$\mathrm{Bu}$ çalışmanın kısıtlııkları başta retrospektif kayıtlardan faydalanılması, hastaların kilo, vücut kitle indeksi gibi malnütrisyonun değerlendirilebileceği verilere ulaşılamaması, hastalara verilen kalori, protein miktarı ve maliyet analizi yapılamaması sayılabilir. Bununla birlikte yaş, cins, hastalık bakımından farksız üç beslenme grubunu karşılaştırmasını önemli buluyoruz.

\section{SONUÇ}

Çocukluk çağında yapılan allojenik HKHN'lerinde hazırlama rejimine bağlı gastrointestinal yan etkiler (kusma, mukozit, ishal gibi) ortaya çıkmadan NGS takılarak fizyolojik beslenme sağlanması, naklin başarısını olumlu etkilerken, komplikasyonların azalmasını sağlar.

Yazarlar arasında çıkar çatışması yoktur. The author declares no conflict of interest. Finansal Destek: yoktur / Funding : none doi: https://doi.org/10.33713/egetbd.644105

\section{KAYNAKLAR}

1. Sureda A, Bader $P$, Cesaro $S$ et al. Indications for allo- and auto-SCT for haematological diseases, solid tumours and immune disorders: current practice in Europe, 2015. Bone Marrow Transplant. 2015 Aug; 50(8): 1037-56.

2. Evans JC, Hirani SP, Needle JJ. Nutritional and PostTransplantation Outcomes of Enteral versus Parenteral Nutrition in Pediatric Hematopoietic Stem Cell Transplantation: A Systematic Review of Randomized and Nonrandomized Studies. Biol Blood Marrow Transplant. 2019 Aug;25(8): e252e259.

3. Fuji S, Einsele H, Savani BN, Kapp M. Systematic Nutritional Support in Allogeneic Hematopoietic Stem Cell Transplant Recipients. Biol Blood Marrow Transplant. 2015 Oct;21(10):1707-13.

4. Lemal R, Cabrespine A, Pereira B et al. Could enteral nutrition improve the outcome of patients with haematological malignancies undergoing allogeneic haematopoietic stem cell transplantation? A study protocol for a randomized controlled trial (the NEPHA study). Trials. 2015 Apr 7; 16:136.

5. Hopman GD, Peña EG, Le Cessie $S$ et al. Tube feeding and bone marrow transplantation. Med Pediatr Oncol. 2003 Jun;40(6):375-9.

6. Guièze R, Lemal R, Cabrespine $A$ et al. Enteral versus parenteral nutritional support in allogeneic haematopoietic stem-cell transplantation. Clin Nutr. 2014 Jun;33(3):533-8.

7. Azarnoush S, Bruno B, Beghin L et al. Enteral nutrition: a first option for nutritional support of children following allo-SCT? Bone Marrow Transplant. 2012 Sep;47(9):1191-5.

8. Bicakli DH, Yilmaz MC, Aksoylar $S$ et al. Enteral nutrition is feasible in pediatric stem cell transplantation patients. Pediatr Blood Cancer. 2012 Dec 15;59(7):1327-9.

9. Gonzales F, Bruno B, Alarcón Fuentes M et al. Better early outcome with enteral rather than parenteral nutrition in children undergoing MAC allo-SCT. Clin Nutr. 2018 Dec;37(6 Pt A):2113-21.

10. Seguy D, Duhamel A, Rejeb MB et al. Better outcome of patients undergoing enteral tube feeding after myeloablative conditioning for allogeneic stem cell transplantation. Transplantation. 2012 Aug 15;94(3):287-94.

11. Zeiser R, Blazar BR. Acute Graft-versus-Host DiseaseBiologic Process, Prevention, and Therapy. N Engl J Med. 2017 Nov 30;377(22):2167-79.

12. Mattsson J, Westin S, Edlund S, Remberger M. Poor oral nutrition after allogeneic stem cell transplantation correlates significantly with severe graft-versus-host disease. Bone Marrow Transplant. 2006 Nov;38(9):629-33.

13. Szeluga DJ, Stuart RK, Brookmeyer R, Utermohlen V, Santos GW. Nutritional support of bone marrow transplant recipients: a prospective, randomized clinical trial comparing total parenteral nutrition to an enteral feeding program. Cancer Res. 
1987 Jun 15;47(12):3309-16.

14. Dropulic LK, Jones RJ. Polyomavirus BK infection in blood and marrow transplant recipients. Bone Marrow Transplant. 2008 Jan;41(1):11-8. 